\title{
Phytophthora cinnamomi na rizosfera de cultivos agrícolas no Sul da Bahia.
}

\author{
Marcos Vinícius Oliveira dos Santos; Daniele Cristina Silva de Araújo; Dilze Maria Argôlo Magalhães; Stela Dalva \\ Vieira Midlej Silva; Marcia Cristina Araújo Paim; Edna Dora Martins Newman Luz.
}

Setor de Fitopatologia, Centro de Pesquisas do Cacau, CEPLAC, CEP 45600-970, Ilhéus-BA, Brasil. 1Parte da Dissertação de Mestrado em Produção Vegetal/UESC do primeiro Autor

Autor para correspondência: Marcos Vinícius Oliveira dos Santos (marcosvos@ymail.com)

Data de chegada: 16/10/2013. Aceito para publicação em: 18/02/2014.
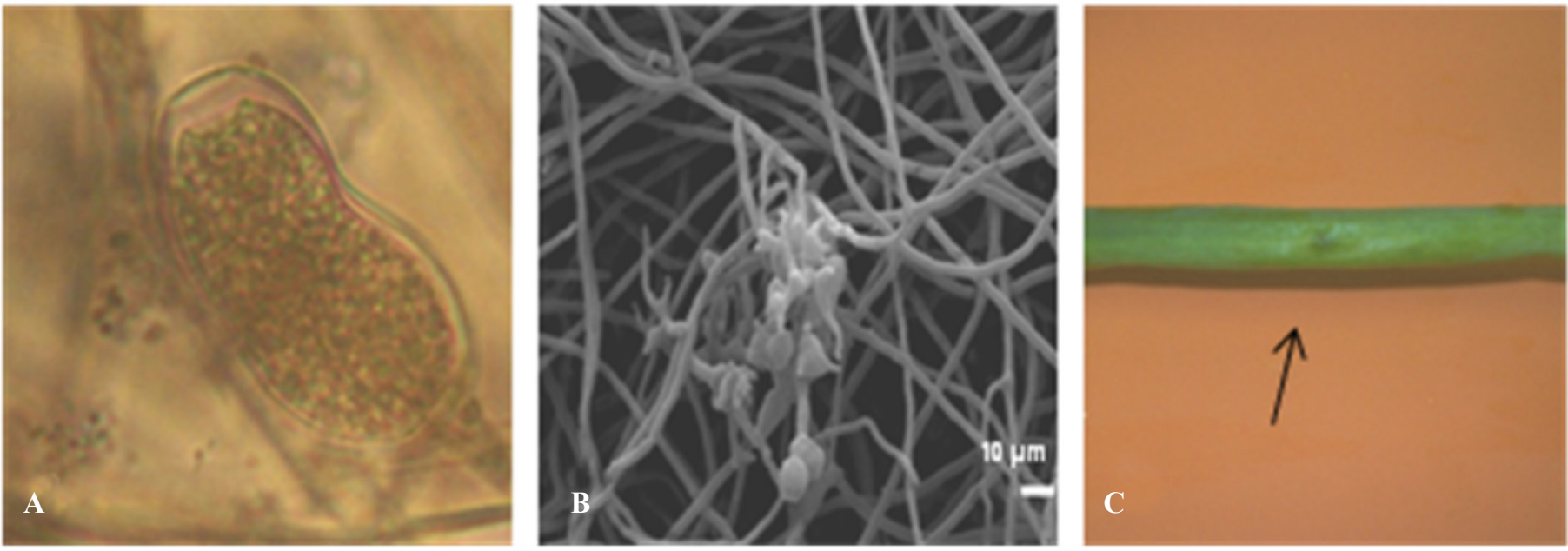

Figura 1. Proliferação interna de esporângio (1367) (A) e intumescimento de hifas de Phytophthora cinnamomi (1188) (B). Lesão causada (seta), em testes in vitro, pelo isolado 1367 em cebolinha (C).

Aproximadamente 24 espécies de Phytophthora foram catalogadas no Brasil (Maia, L.C.; Carvalho Jr., A.A. (Coords.) 2010. Lista de espécies: fungos. In: Forzza, R.C. (Org.) et al. Catálogo de plantas e fungos do Brasil. pp. 90-261), entre estas, P. cinnamomi Rands destacase como uma das mais agressivas e possui mais de 1.000 hospedeiros vegetais no globo terrestre (Gallegly, M.E.; Hong, C. Phytophthora: Identifying Species by Morphology and DNA Fingerprints 158p. 2008). Apesar da existência de diversos hospedeiros de P. cinnamomi no Sul da Bahia, não havia relatos deste fitopatógeno em cultivos agrícolas da região. Por meio de prospecções realizadas, entre julho de 2008 a junho de 2009, em propriedades rurais direcionadas à agricultura familiar nos municípios de Ilhéus e Ituberá, Bahia, foram obtidos cinco isolados de Phytophthora a partir do isolamento de amostras de solo da rizosfera de helicônia bihai I (Heliconia bihai L. cv. Lobster Claw I) (1188), bastão do imperador (Etlingera elatior (Jack) R. M. Smith) (1410), cebolinha (Allium fistulosum L.) (1367) e alface (Lactuca sativa L.) $(1368 \mathrm{e}$ 1369) em meio seletivo PARPH (Kannwischer, M.E.; Mitchell, D.J. Phytopathology 68: 1760-1765. 1978). Os isolados foram identificados por critérios morfofisiológicos e a compatibilidade sexual dos mesmos foi determinada pelo método de sanduíche (Luz, E.D.M.N. et al. Glossário ilustrado de Phytophthora: técnicas especiais para o estudo de Oomicetos 204p. 2008). Testes de patogenicidade foram realizados pelo método de disco de micélio em folhas destacadas dos hospedeiros, em câmara úmida, com 10 repetições/isolado. Culturas axênicas de $P$. cinnamomi não esporularam em meio de cultivo cenoura-ágar
(CA), por isso adicionou-se extrato de solo não esterilizado (Ribeiro, O.K. A source book of the genus Phytophthora 417p. 1978) ao meio líquido de cenoura para estimular a formação de esporângios. Após sete dias de incubação a $25{ }^{\circ} \mathrm{C}$, em meio CA, observaram-se colônias estreladas (1368 e 1410), difusas (1367 e 1369) e petaloide, tipo crisântemo (1188). O micélio aéreo das colônias variou de cotonoso (1410) a floculoso (outros isolados). Os esporângios mediram 39,5 x 24,6 $\mu \mathrm{m}$, eram predominantemente elipsoides e ovoides, não decíduos, com papila inconspícua e abertura média do poro apical de $6,9 \mu \mathrm{m}$. Os isolados formaram clamidósporos com diâmetro médio de 24,9 $\mu \mathrm{m}$. A proliferação interna de esporângios (Figura 1A) e a presença de intumescimento de hifas (Figura 1B) foram observadas em todas as culturas, as quais não cresceram à temperatura de $35^{\circ} \mathrm{C}$. $\mathrm{O}$ isolado 1188 é do tipo compatível A1 e todos os outros são do tipo A2. Os cinco isolados foram patogênicos aos seus respectivos cultivos de origem (exemplo Figura 1C). A partir das observações realizadas, os isolados foram identificados como Phytophthora cinnamomi Rands. Não há registros desta espécie como fitopatógeno dos cultivos em que os isolados foram obtidos. Phytophthora cinnamomi foi diagnosticada pela primeira vez no Sul da Bahia, em 2009, na rizosfera de Parinari alvimii Prance, Manilkara maxima Pennington e Harleyodendron unifoliolatum Cowan, espécies endêmicas ao bioma Mata Atlântica (Luz, E.D.M.N. et al. Phytopathology 99: S77. 2009). Estes são os primeiros registros deste fitopatógeno em cultivos agrícolas na região Sul da Bahia. 